\title{
DAB2 wt Allele
}

National Cancer Institute

\section{Source}

National Cancer Institute. DAB2 wt Allele. NCI Thesaurus. Code C52067.

Human DAB2 wild-type allele is located within $5 p 13$ and is approximately $52 \mathrm{~kb}$ in length. This allele, which encodes disabled homolog 2 protein, plays a role in the inhibition of cell proliferation. Down-regulation or complete loss of DAB2 gene expression is associated with certain cancers such as breast cancer and ovarian epithelial carcinomas. 